\title{
Clipping frequency and intensity effects on big bluestem yield, quality, and persistence
}

\author{
J.R. FORWOOD AND M.M. MAGAI
}

\begin{abstract}
Authors are supervisory range scientist (deceased), USDA-ARS, Rangeland Resources Research Unit, I701 Center Avenue, Fort Collins, Colo. 80526; and graduate research assistant, Room 200A, Waters Halls, University of Missouri, Columbia, Mo. 65211.
\end{abstract}

\section{Abstract}

This study was initiated to determine the effects of defoliation frequency (based on amount of growth present), intensity, and length of grazing season on quantity and quality of big bluestem (Andropogon gerardi Vitman) in the Southern corn belt and to provide further data regarding the reasons for rapid quality decline of warm-season grasses. Three clipping frequencies (when plants reached heights of $30,41,51 \mathrm{~cm}$ ) at 2 intensities (stubble heights of 10 and $20 \mathrm{~cm}$ ) were imposed on established plots of pure big bluestem (cv. Kaw). Harvest season length was studied by terminating clipping on 15 August and 15 September as 2 separate treatments. Two years of data indicated that big bluestem regrows insufficiently after 15 August to warrant additional harvests under the imposed managements. Prolonged regrowth and leaving a short stubble of $10 \mathrm{~cm}$ resulted in greatest yield. Short stubble led to greater reductions in nonstructural carbohydrates, but did not damage the stand compared to pre-study measurements. Nonstructural carbohydrate levels and stand composition improved with taller stubble. In vitro dry matter digestibility and crude protein were higher on treatments clipped to leave a $10-\mathrm{cm}$ stubble. The greatest proportion of leaves resulted from treatments where a 20-cm stubble remained. These results agree with studies indicating that leaf maturity is more responsible for lower quality forage than is the amount of stem material present in the stand. Our results indicate heavy use can be more safely accomplished in the Southern corn belt than for areas to the west because big bluestem can be more intensively defoliated in the Southern corn belt $(10-\mathrm{cm})$ than that recommended for other areas $(20$ to $40 \mathrm{~cm})$.

Key Words: In vitro dry matter digestibility, Andropogon gerardi Vit, defoliation intensity, grazing season, warm-season grasses, forage quality, harvest regimes

Warm-season $\left(\mathrm{C}_{4}\right)$ grasses such as switchgrass ( Panicum virgatum L.), Caucasian bluestem [Bothriochloa caucasica (Trin.) C.E. Hubbard], and big bluestem (Andropogon gerardi Vitman) have been shown to provide summer forage in complementary grazing systems with cool-season species. Conard and Clanton (1963), Roundtree et al. (1974), and Krueger et al. (1974) have reported increased summer steer gains; 2 to 3 times greater carrying capacity over tall fescue (Festuca arundinacea Schreb.) during summers; and $83 \%$ increased beef gains in Nebraska, Missouri, and South Dakota, respectively.

A major disadvantage of warm-season grasses is their apparent low quality compared to cool-season grasses, especially at advanced stages of growth. Consequently, the timing, intensity, and redefoliation of these grasses is extremely important not only to quality but to persistence as well.

Major factors shown in the seasonal decline of forage quality include a decrease in leaf:stem and an increasing proportion of dead leaves in the sward (Beaty et al. 1968). Perry and Balten- sperger (1979) indicated that leaf maturation was responsible for declining quality. They found a rapid decline in leaf crude protein and IVDMD of big bluestem throughout the growing season. In contrast, Twidwell et al. (1986) observed a faster decline in stem IVDMD than leaf blade IVDMD with maturation of switchgrass and identified the stem as the major morphological component influencing forage quality.

Dry matter yield of warm-season grasses was reduced as frequency of defoliation increased, and grass persistence was poor when plants were stressed by too frequent or too intense defoliation (Anderson and Matches 1983, Ethredge et al. 1973). Continuous removal of top growth close to ground level throughout the growing season does not allow sufficient leaf area for photosynthesis and manufacture of carbohydrate reserves. More frequent clipping of big bluestem to $4 \mathrm{~cm}$ reduced carbohydrate reserves compared to less frequent clippings (Owensby et al. 1974).

Our objective was to evaluate yield, leaf to stem (L:S), quality, and stand persistence of big bluestem under 6 clipping regimes aimed at simulated grazing in the Southern corn belt. Through this an additional goal was to obtain information which will aid in solving the controversy regarding factors responsible for seasonal quality decline in warm-season species.

\section{Materials and Methods}

'Kaw' big bluestem was seeded on 15 June 1981 at the University of Missouri Agronomy Research Center (Bradford farm). Soil type was a Mexico silt loam (fine montimorillonitic, mesic Udollic Ochraqualf). Plot size was 1.8 by $3.7 \mathrm{~m}$. Annual management included application of $56-34-67 \mathrm{~kg} \mathrm{ha}^{-1}$ of actual nitrogen, phosphorus, and potassium. From 1982 to 1985 growth was stockpiled and burned annually between 5 and 15 April.

Six defoliation treatments were imposed in 1985 and 1986. The treatments were:

1. Clipped when a 30-cm height was reached to leave either a $10-\mathrm{cm}$ or $20-\mathrm{cm}$ stubble $(30 / 10$ and $30 / 20$ treatments, respectively).

2. Clipped when a $41-\mathrm{cm}$ height was reached to leave either a $10-\mathrm{cm}$ or $20-\mathrm{cm}$ stubble $(41 / 10$ and $41 / 20$ treatments, respectively).

3. Clipped at $51-\mathrm{cm}$ height was reached to leave either a $10-\mathrm{cm}$ or $20-\mathrm{cm}$ stubble ( $51 / 10$ and $51 / 20$, respectively).

Heights were measured with a meter rule. The average canopy height for fully grown big bluestem in Missouri is 1 to 3 meters.

The study began by clipping on 9 May 1985 when big bluestem attained $30 \mathrm{~cm}$ in height. Plots were harvested to the $10-$ to $20-\mathrm{cm}$ stubble height each time the specified plant height $(30,41$, or $51 \mathrm{~cm})$ was attained. Number of harvests varied among treatments from year to year, dependent upon the time required for the plants to reach the given plant height (Table 1).

Each year's harvest was terminated on one-half of the treatments 
Table 1. Treatment initial cutting height $(30,41$, or $51 \mathrm{~cm}$ frequencies) and stubble height (intensities -10 or $20 \mathrm{~cm}$ ), cutting dates and total number of cuts for big bluestem during 1985 and 1986.

\begin{tabular}{lllll}
\hline \hline Treatments & $\begin{array}{c}1985 \\
\text { Cutting dates }\end{array}$ & $\begin{array}{c}\text { Total } \\
\text { cuts }\end{array}$ & $\begin{array}{c}1986 \\
\text { Cutting dates }\end{array}$ & $\begin{array}{c}\text { Total } \\
\text { cuts }\end{array}$ \\
\hline $\mathrm{cm} / \mathrm{cm}$ & $5 / 9,5 / 28,6 / 18$, & 7 & $5 / 14,6 / 2,6 / 16$, & 6 \\
$30 / 10$ & $7 / 2,7 / 24,8 / 21$, & & $7 / 2,7 / 21,8 / 19$. & \\
& $9 / 13$. & & & \\
& $5 / 9,5 / 17,5 / 28$, & 11 & $5 / 14,5 / 27,6 / 2$, & 10 \\
$30 / 20$ & $6 / 10,6 / 21,6 / 28$, & & $6 / 11,6 / 19,6 / 30$, & \\
& $7 / 8,7 / 18,7 / 26$, & & $7 / 10,7 / 21,7 / 31$ & \\
& $8 / 21,9 / 13$. & & $8 / 14$. & \\
$41 / 10$ & $5 / 15,6 / 10,7 / 2$, & 5 & $5 / 22,6 / 9,6 / 24$, & 5 \\
& $7 / 28,9 / 6$. & & $7 / 16,8 / 11$. & \\
$41 / 20$ & $5 / 15,5 / 31,6 / 10$, & 7 & $5 / 14,5 / 27,6 / 9$, & 8 \\
& $6 / 26,7 / 8,7 / 24$, & & $6 / 19,6 / 30,7 / 16$, & \\
& $8 / 21$. & & $7 / 29,8 / 19$. & \\
$51 / 10$ & $5 / 20,6 / 18,7 / 18$, & 4 & $5 / 22,6 / 11,7 / 2$, & 7 \\
& $9 / 6$. & & $7 / 29$. & \\
$51 / 20$ & $5 / 20,6 / 10,7 / 8$, & 5 & $5 / 22,6 / 2,6 / 16$, & 7 \\
& $7 / 28,8 / 21$. & & $6 / 30,7 / 16,7 / 31$, & \\
& & & $9 / 19$. & \\
\hline
\end{tabular}

on 15 August and 15 September on the remainder to represent different lengths of grazing season.

\section{Field Data Collection}

At each harvest date, a $0.5 \mathrm{~kg}$ sample was hand-clipped randomly from each plot at treatment heights and separated into leaf blade and stem plus sheath portions to evaluate leaf and stem percentage for various treatments and for forage quality determination. Leaves were separated at the collar so that only leaf blades were considered as leaf portions while stem portions included leaf sheaths and elongated stem. Total herbage yield was harvested from a 0.9 by $3.7 \mathrm{~m}$ strip. Leaf, stem, and a herbage subsample obtained from the total harvested material for each plot, were weighed green, then dried for at least 3 days in a forced draft oven at $40^{\circ} \mathrm{C}$ for quality analyses. Leaf and stem yields from entire plots were calculated from total yield using percentages of each as determined from hand separations. All forage yields were reported on a dry matter (DM) basis. The remainder of the plots was harvested similar to the sampled strip. Dried samples were ground in a Wiley mill to pass a 1-mm screen and stored in sealed containers for laboratory analyses.

Root and crown samples were collected in April 1985 and 1986 and March 1987 to determine concentration of total nonstructural carbohydrates (TNC) at the beginning of the growing season. At least 3 plants from each plot were selected randomly, removed to a depth of $15-\mathrm{cm}$, and washed clean of soil material. Roots were trimmed to approximately $7.6 \mathrm{~cm}$ below, and crowns $3.5 \mathrm{~cm}$ above, the root-stem junction and washed in cold water. Samples were dried at $100^{\circ} \mathrm{C}$ for 1 hour, then at $65^{\circ} \mathrm{C}$ for 48 hours, ground to pass a $1-\mathrm{mm}$ screen, and stored in sealed plastic containers for laboratory analyses.

Basal cover of big bluestem was estimated using the point method in May 1985 and 1986, and April 1987, when plants were 20 to $25 \mathrm{~cm}$ tall. A frame of 10 pins $5.1 \mathrm{~cm}$ apart was randomly placed in the middle one-third of each plot with the pins at an angle of $\mathbf{4 5}$ degrees from vertical. All pins contacting a tiller at the soil surface were recorded. Three measurements per plot were taken. Percentage cover was calculated using the formula:

Relative cover $=100 \times n / 30$ where $n=$ number of pins touching a base of a big bluestem tiller.

\section{Laboratory Analyses}

In vitro dry matter digestibility was determined by the direct acidification method as described by Marten and Barnes (1980). Duplicate samples of leaf blades, stems (including leaf sheaths), and subsamples of total herbage were analyzed separately. Means of the duplicates were used in analyses of variance. Leaf and stem portions of big bluestem were analyzed for total nitrogen using a LECO FP-28 Nitrogen Determinator (Sweeny and Rexroad 1987). Nitrogen values were multiplied by 6.25 to obtain crude protein (CP).

Total nonstructural carbohydrates (TNC) were measured by extracting with $0.2 \mathrm{~N} \mathrm{H}_{2} \mathrm{SO}_{4}$ (Smith et al. 1969) and titrating reducing sugars by the Shaffer-Somogyi technique outlined by Heinze and Murneek (1940).

\section{Experimental Design}

Experimental design was a repetition ( 2 years on 1 site) of a split plot with 3 replicates. Whole plots were the 2 lengths of harvest season. Split plots were plant height at cutting/stubble height combinations in a factorial arrangement. The $F$ tests for whole plots used pooled replicates nested in whole plots and years as the error terms. Other $\mathrm{F}$ tests used the split plot error mean squares. All effects were considered model I. Analyses of variance were conducted on yield, quality, and persistence data.

Analysis of variance for dry matter yields of individual treatments were summed across harvests in each year to give a seasonlong total, while means over harvests were considered for forage quality. Persistence data were analyzed directly each year. Trends in response variables were investigated using orthogonal polynomials. Tests for parallelism and equal curvature were also done. All tests used 0.5 as Type I error rate.

\section{Results and Discussion}

\section{Dry Matter Yield}

Total dry matter yield averaged over 2 years was 2,420 and 2,650 $\mathrm{kg} \mathrm{ha}^{-1}$ for the 15 August and 15 September terminations, respectively, while average IVDMD values were 480 and $492 \mathrm{~g} \mathrm{~kg}^{-1}$ for 15 August and 15 September, respectively. Defoliation treatment did not influence whether sufficient regrowth existed until 15 August or 15 September. The total number of harvests depended on the amount of time elapsed from previous harvest and the rate of growth. Because no significant differences were obtained between the 15 August or 15 September harvest termination dates or between years, discussion will focus on effects of clipping frequency (height at clipping) and intensity (stubble height) on big bluestem averaged over 2 years.

Greatest yield was found with long regrowth (clipping when 51 $\mathrm{cm}$ height was attained) and clipping to a 10-cm stubble, compared to treatments which were clipped frequently to a $20-\mathrm{cm}$ stubble (Table 2). Anderson and Matches (1983) reported that cutting Caucasian bluestem and switchgrass to a $15-\mathrm{cm}$ stubble height gave

Table 2. Effects of clipping frequency and intensity on total dry matter yield (TDM), L:S and leaf yield of big bluestem (Average of 2 years).

\begin{tabular}{|c|c|c|c|c|}
\hline $\begin{array}{l}\text { Frequency } \\
\text { (height) } \\
\text { at cut) }\end{array}$ & $\begin{array}{c}\text { Intensity } \\
\text { (stubble } \\
\text { remaining) }\end{array}$ & TDM & L:S & Leaf yield \\
\hline$(\mathrm{cm})$ & (cm) & $\left(\mathrm{kg} \mathrm{ha}^{-1}\right)$ & & $\left(\mathrm{kg} \mathrm{ha}^{-1}\right)$ \\
\hline $\begin{array}{l}30 \\
41 \\
51\end{array}$ & $\begin{array}{l}10 \\
20 \\
10 \\
20 \\
10 \\
20\end{array}$ & $\begin{array}{l}2624 \\
1928 \\
2510 \\
2176 \\
3879 \\
2107\end{array}$ & $\begin{array}{l}0.85 \\
0.91 \\
0.83 \\
0.88 \\
0.79 \\
0.84\end{array}$ & $\begin{array}{l}2230 \\
1755 \\
2083 \\
1915 \\
3064 \\
1770\end{array}$ \\
\hline $\operatorname{LSD}(0.05)$ & & 759 & 0.05 & 578 \\
\hline
\end{tabular}



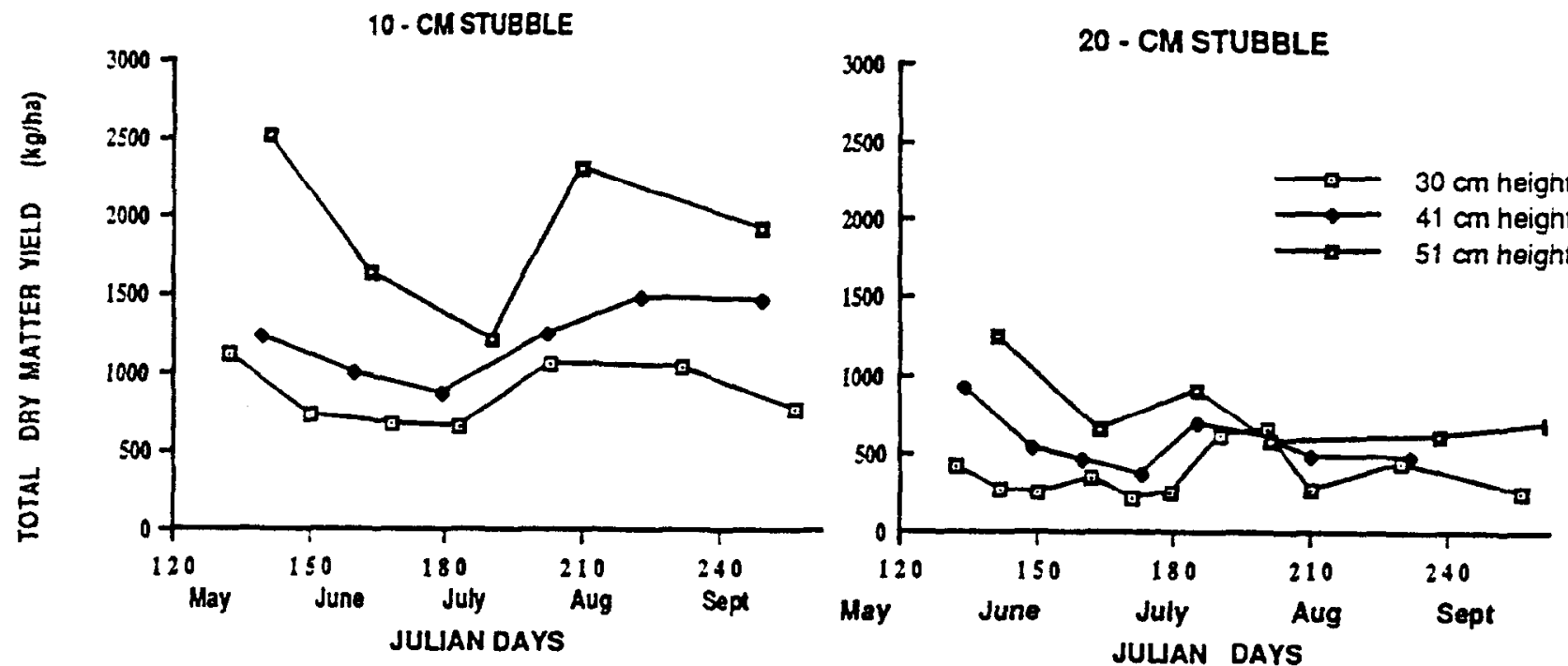

10- CM STUBBLE
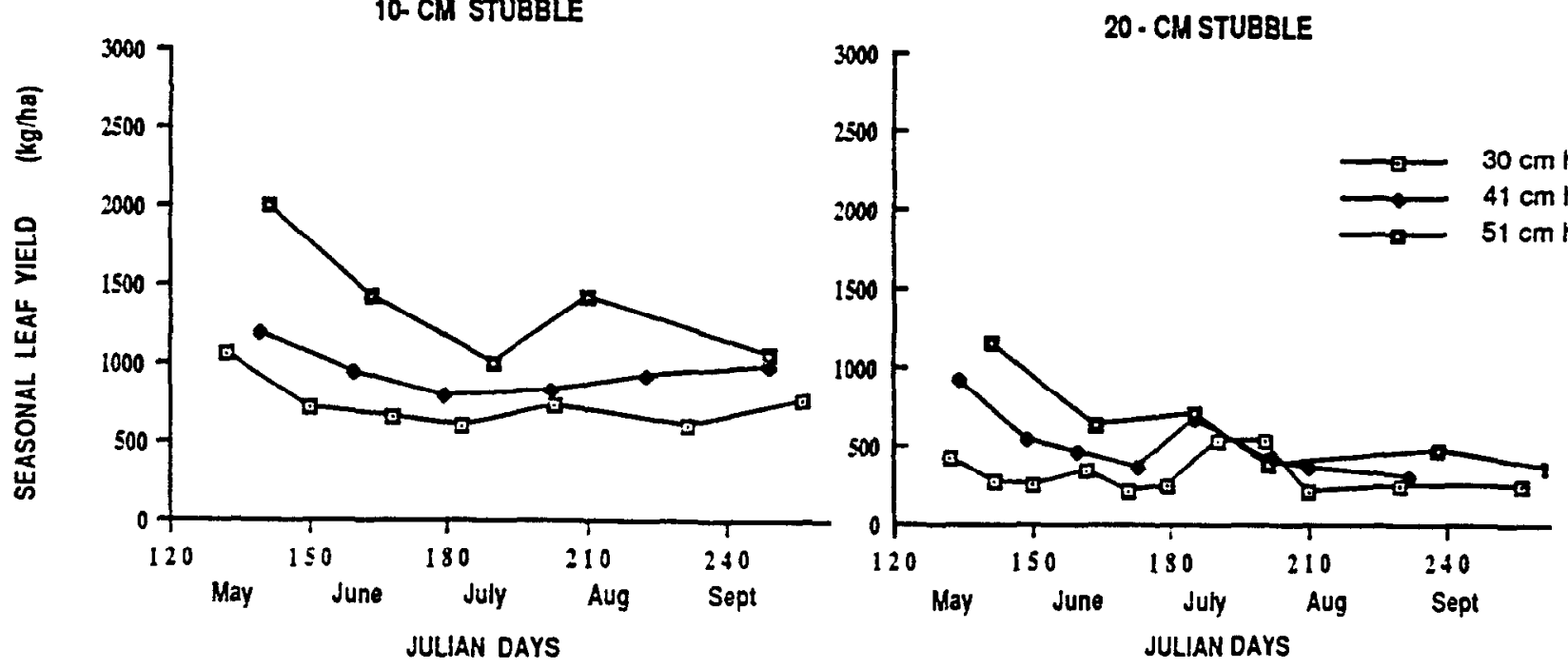

Fig. 1. Total dry matter (A) and leaf yield (B) trends of big bluestem (2-year average) when harvested at 10- and 20-cm stubble heights, when plants reached heights of 30, 41, and $51 \mathrm{~cm}$.

higher yields than when cut to a 20 -cm stubble. Ethredge et al. (1973) found a similar response for bermudagrass [Cynodon dactylon (L.)]. Frequent clipping has often resulted in reduced yield compared to less frequent harvests (Ethredge et al. 1973, bermudagrass; Owensby et al. 1974, big bluestem). Orthogonal polynomials (Table 3) reveal the yield responses of big bluestem to cutting frequency under $10-$ and $20-\mathrm{cm}$ intensities was not parallel. Lower cutting height $(10 \mathrm{~cm})$ increased total dry matter yield at a more rapid rate than the $20-\mathrm{cm}$ height as forage was harvested less frequently $(51-\mathrm{cm})$. Table 2 shows the same trend for stem yield (significant slope of the line for $10-\mathrm{cm}$ intensity but not for $20-\mathrm{cm}$ ) with the lines not parallel. Since regression of leaf yield revealed the lines for harvest frequency to be parallel with different intensities, we speculated the total dry matter differences observed at 41 and $51-\mathrm{cm}$ may have been due to more stem material when big bluestem is harvested at $51-\mathrm{cm}$ frequency. Trends (averages over 2 years) for total dry matter and leaf yield are shown in Figure 1.

\section{Leaf and Stem Composition}

The 51 / 10 treatment yielded $40 \%$ more TDM and $30 \%$ more leaf blade DM than any other treatment. However, greatest leaf:stem was obtained from treatments clipped to leave a $20-\mathrm{cm}$ stubble (Table 3). This may have resulted from less elongated stem being removed when clipped at a higher level $(20 \mathrm{~cm}$ stubble). There were significant stem DM yield differences due to intensity, frequency, and year $X$ frequency interaction (Table 2). Low clipping $(10 \mathrm{~cm}$ 
Table 3. Summary of statistical significance from $F$ tests for total dry matter yield (TDM), leaf yield, stem yield and L:S of Kaw big bluestem in 1985 and 1986.

\begin{tabular}{lcccc}
\hline \hline \multirow{2}{*}{$\begin{array}{l}\text { Source of } \\
\text { variation }\end{array}$} & TDM & \multicolumn{4}{c}{ Leaf yield } & Stem yield & L:S \\
\cline { 2 - 5 } & \multicolumn{4}{c}{$\mathbf{k g ~ h a}^{-1}$} \\
\hline Season (S) & NS & NS & NS & NS \\
Frequency (F) & $*$ & NS & $* *$ & $* *$ \\
Intensity (I) & $* *$ & $* *$ & $* *$ & $* *$ \\
S $\times$ F & NS & NS & NS & NS \\
S $\times$ I & NS & NS & NS & NS \\
F $\times$ I & $*$ & $*$ & NS & NS \\
S $\times$ F $\times$ I & NS & NS & NS & NS \\
F linear:I1 & $* *$ & $*$ & $* *$ & $* *$ \\
F linear:I2 & NS & NS & NS & $*$ \\
Parallelism & $*$ & NS & $*$ & NS \\
F quadratic:I1 & $*$ & $*$ & $*$ & NS \\
F quadratic:I2 & NS & NS & NS & NS \\
Equal quadratic & NS & NS & NS & NS \\
CV & 6.2 & 33.5 & 68.5 & 6.4 \\
\hline
\end{tabular}

**** Significant at 0.05 and 0.01 level, respectively.

NS Nonsignificant

II $10 \mathrm{~cm}$ clipping intensity

I2 $20 \mathrm{~cm}$ clipping intensity

resulted in higher average stem yield $\left(\bar{x}=610 \mathrm{~kg} \mathrm{ha}^{-1}\right)$ than for the 20 -cm stubble $\left(\bar{x}=251 \mathrm{~kg} \mathrm{ha}^{-1}\right)$. There were differences between years with frequencies for 41 and $51-\mathrm{cm}$ frequency $(P<0.05)$; however, no discernable trend exists. In 1985, harvesting at the 51-cm frequency yielded more stem material than any other treatment. Most stem material was obtained after stem elongation of big bluestem which usually occurs during mid-July in Missouri (Finch 1974).

\section{In Vitro Dry Matter Digestibility}

Average whole plant digestibility decreased as plants were allowed greater regrowth (Table 4). Total digestible dry matter

Table 4. Effect of clipping frequency (based on plant height) and intensity (stubble remaining) on in vitro dry matter digestibility (IVDMD) of whole plant, leaf and stem portions of big bluestem (Average of 2 years).

\begin{tabular}{|c|c|c|c|c|c|c|}
\hline \multirow{3}{*}{$\begin{array}{l}\text { Frequency } \\
\text { (cm) }\end{array}$} & \multicolumn{2}{|c|}{ Whole plant } & \multicolumn{2}{|c|}{ Leaf } & \multicolumn{2}{|c|}{ Stem } \\
\hline & \multicolumn{2}{|c|}{ Intensity (cm) } & \multicolumn{2}{|c|}{ Intensity $(\mathrm{cm})$} & \multicolumn{2}{|c|}{ Intensity $(\mathrm{cm})$} \\
\hline & 10 & 20 & 10 & 20 & 10 & 20 \\
\hline & \multicolumn{6}{|c|}{$\ldots$} \\
\hline 30 & 50 & 50 & 51 & 50 & 45 & 42 \\
\hline 41 & 52 & 47 & 52 & 47 & 43 & 40 \\
\hline 51 & 45 & 48 & 47 & 48 & 44 & 45 \\
\hline $\operatorname{LSD}(0.05)$ & \multicolumn{2}{|c|}{3} & \multicolumn{2}{|c|}{2} & \multicolumn{2}{|c|}{3} \\
\hline
\end{tabular}

$(D D M)$ yield (total yield $\times$ digestibility) was greatest for $51 / 10$ $\left(1,761 \mathrm{~kg} \mathrm{ha}^{-1}\right)$ compared to $30 / 10$ and $41 / 10$ treatments $(1,315$ and $1,302 \mathrm{~g} \mathrm{~kg}^{-1}$, respectively). Yields of DDM when leaving a $20-\mathrm{cm}$ stubble were considerably lower $\left(966,1,014\right.$, and $1,001 \mathrm{~kg} \mathrm{ha}^{-1}$ for $30 / 20,41 / 20$, and $51 / 20$ treatments, respectively). Digestibility was significantly lower $(1.2 \%)$ in 1986 than in 1985 , when herbage was cut at the same frequencies resulting in a frequency $X$ year interaction (Table 5). This was perhaps due to higher temperature and $15.7 \mathrm{~cm}$ less precipitation during June, July, and August 1986.

Orthogonal polynomials reveal IVDMD's for the whole plant and leaf material at the 2 intensities not to be parallel (Table 5). Harvests at $10 \mathrm{~cm}$ maintained greater digestibility over time than those taken at $20 \mathrm{~cm}$, although there was a sharp decline in IVDMD while the plants grew from 41 to $51 \mathrm{~cm}$. Stem digestibility responses showed no slope or differences in digestibility due to frequency or intensity. Clipping frequency did not influence leaf IVDMD in 1985 but did in 1986, indicating that environmental
Table 5. Summary of statistical significance from $F$ tests for whole plant, leaf and stem IVDMD, and leaf and stem protein of big bluestem.

\begin{tabular}{lcccccc}
\hline & \multicolumn{3}{c}{ IVDMD } & & \multicolumn{2}{c}{ Protein } \\
\cline { 2 - 4 } \cline { 6 - 7 } Source of & Whole & Leaf & Stem & & Leaf & Stem \\
\hline Season (S) & $N S$ & NS & NS & & NS & NS \\
Frequency (F) & $* *$ & $* *$ & NS & & $* *$ & NS \\
Intensity (I) & $N S$ & $* *$ & NS & & NS & NS \\
S $\times$ F & $*$ & $*$ & NS & & NS & NS \\
S $\times$ I & $N S$ & NS & NS & & NS & NS \\
F $\times$ I & $* *$ & $* *$ & NS & & NS & NS \\
S F F I & $N S$ & NS & NS & & NS & NS \\
F linear:I1 & $* *$ & $* *$ & NS & & $* *$ & NS \\
F linear:I2 & $*$ & $*$ & NS & & $* *$ & NS \\
Parallelism & $N S$ & $*$ & NS & & NS & NS \\
F quadratic:I1 & $* *$ & $* *$ & NS & & NS & NS \\
F quadratic:I2 & $N S$ & $* *$ & NS & & NS & NS \\
Equal quadratic & $* *$ & $* *$ & NS & & NS & NS \\
CV & 6.4 & 3.8 & 9.5 & & 8.4 & 10.3 \\
\hline
\end{tabular}

*,**Significant at 0.05 and 0.01 level, respectively.

NS Nonsignificant

II $10 \mathrm{~cm}$ clipping height

I2 $20 \mathrm{~cm}$ clipping height

differences between the 2 seasons could have an effect. Total leaf DDM yield (total leaf yield $X$ digestibility) was greatest for the $51 / 10$ treatment $\left(1,382,1,059\right.$, and $1,122 \mathrm{~kg} \mathrm{ha}^{-1}$ for $51 / 10,41 / 10$, and $30 / 10$, respectively). Similar to total DDM yield, leaf DDM yield was considerably lower for the $20-\mathrm{cm}$ stubble heights (853, 881 , and $855 \mathrm{~kg} \mathrm{ha}^{-1}$ for $51 / 20,41 / 20$, and $30 / 20$, respectively).

Stem IVDMD was not affected by clipping frequency or intensity (Table 5) indicating, as did Perry and Baltensperger (1979), that the decline in quality as plants mature was due more to decline in digestibility of maturing leaves than to large differences in quality between leaf and stem tissue. Some quality decline may be attributed to the increasing proportion of stems as plants mature. Plants clipped to leave a $20-\mathrm{cm}$ stubble had little proportion of stem dry matter compared to those clipped to leave a $10-\mathrm{cm}$ stubble. However, whole plant quality was generally higher when plants were clipped $10 \mathrm{~cm}$ from the ground.

\section{Crude Protein}

Big bluestem contained more $\mathrm{CP}$ in leaves (11.7\%) than in stems (6.7\%). Longer regrowth periods led to significant decline in leaf $\mathrm{CP}[12.6,11.6$, and $10.9 \%$ for 30,41 , and $51-\mathrm{cm}(P<0.05 \mathrm{LSD}=$ $0.6)$ height at clipping, respectively]. Responses at both clipping intensities were linear and parallel (Table 5). No differences were found in stem protein levels at similar clipping heights, nor was there a significant linear or quadratic response to the treatments. The lines for stem protein values were parallel (Table 5) indicating maturity of the leaf was responsible for declining plant quality. Reserves of nitrogen in big bluestem are known to decline during periods of active growth Owensby et al. 1977). These results agreed that as time for plant growth before harvest lengthened, nitrogen concentration declined.

There was a significant crude protein year $X$ season interaction. In 1985 leaf crude protein was higher for the 15 August final harvest date than for 15 September, while the reverse was true of 1986. Like IVDMD, this could be attributed to environmental differences between the 2 years.

Effect of harvest intensity on stem CP was modified by years. In 1985 , clipping to $10 \mathrm{~cm}$ resulted in higher CP levels $(7.3 \%)$ compared to $20-\mathrm{cm}$ clipping intensity $(6.7 \%)$; however, the reverse was true in 1986 (6.2 and 6.8\% for 10 and $20-\mathrm{cm}$ intensity, respectively). No explanation is available for these differences.

\section{Persistence}

Big bluestem regrowth failed to reach height requirements for 
the 15 September harvest which did not allow testing the effect of late harvest on persistence. Treatments clipped to a short stubble remained similar in ground cover while those clipped to a $20-\mathrm{cm}$ stubble showed a marked stand improvement from year to year (Table 6).

Table 6. Big bluestem composition as a percentage of total basal cover as affected by sampling date and intensity. Treatments occurred during 1985 and 1986.

\begin{tabular}{|c|c|c|}
\hline Sampling date & $\begin{array}{c}\text { Intensity } \\
10 \mathrm{~cm}\end{array}$ & $\begin{array}{c}\text { Intensity } \\
20 \mathrm{~cm}\end{array}$ \\
\hline & \multicolumn{2}{|c|}{$\ldots \ldots \ldots$ Ground Cover $(\%) \ldots \ldots$} \\
\hline April 1985 & 23 & 22 \\
\hline May 1986 & 27 & 49 \\
\hline April 1987 & 22 & 61 \\
\hline LSD (0.05) & \multicolumn{2}{|c|}{7.3} \\
\hline
\end{tabular}

\section{Total Nonstructural Carbohydrates}

Leaving a short stubble $(10 \mathrm{~cm})$ resulted in lower $(P<0.05)$ TNC concentrations in crowns of big bluestem with the 41 and $51-\mathrm{cm}$ clipping frequency (Table 7) compared to the 20-cm intensities over the 2-year period. Owensby et al. (1974) reported a linear downward trend in TNC as clipping intensity of big bluestem increased. The similarity of TNC concentrations resulting from the $30 / 10$ and $30 / 20$ (same growth period) treatments to that obtained from the 41 / 10 and $51 / 10$ treatments (longer regrowth periods and shorter stubble) lead us to speculate that frequent removal of top growth requires use of plant energy similar to intensive defoliation at fewer frequencies. Length of harvest season had no significant effect on total nonstructural carbohydrate levels, because regrowth was very limited after 15 August.

Table 7. Total nonstructural carbohydrate levels of big bluestem as affected by clipping frequency and harvest intensity. Data are averaged for 1986 and 1987 sampling dates.

\begin{tabular}{|c|c|c|}
\hline \multirow[b]{2}{*}{ Clipping frequency } & \multicolumn{2}{|c|}{ Clipping intensity } \\
\hline & 10 & 20 \\
\hline$(\mathrm{cm})$ & $\ldots \ldots \ldots$ & $-\ldots \ldots$ \\
\hline 30 & 3.7 & 3.3 \\
\hline 41 & 2.9 & 4.4 \\
\hline 51 & 4.0 & 5.3 \\
\hline $\operatorname{LSD}(0.05)$ & \multicolumn{2}{|c|}{0.8} \\
\hline
\end{tabular}

Reserve levels of carbohydrates (averaged over treatments) were significantly lower in 1987 than in 1986 (means of 4.4 and $3.4 \%$, respectively) indicating the effects of clipping carry over into at least the next growing season (Kinsinger and Hopkins 1961). Levels of TNC found in the present study (3.5 and $4.3 \%$ for $10-\mathrm{cm}$ and $20-\mathrm{cm}$ intensities, respectively) were similar to those found in the Kansas Flint Hills after 1 year's rest from light grazing (McKendrick et al. 1975) or under continuous or intensive grazing (Owensby et al. 1977).

\section{Conclusions}

Forage production and quality of big bluestem is strongly affected by frequency, intensity, and time of defoliation. We hypothesized that big bluestem could be harvested more intensively and later in the fall ( 15 September) in the Southern corn belt than the Great Plains to the west, but found that under the harvest regimes tested, there were no differences between 15 August and 15 September harvests. The best way to utilize big bluestem under those growing conditions was to allow sufficient regrowth between defoliations ( $41-\mathrm{cm}$ or $16 \mathrm{inch}$ ) for the accumulation of reserve carbohydrates and then to leave a short stubble (10-cm or 4 inch) allowing high quality regrowth to occur. The similarity in ground cover values between pre-study and that at termination of the study, lead us to believe that if necessary big bluestem can be more intensively defoliated in the Southern corn belt than that recommended farther west $(20-40 \mathrm{~cm})$ (Anderson 1986). These data agree with the theory that in regions where plant growth is not limited by moisture, big bluestem, like switchgrass, may be defoliated more severely than recommended in the drier Great Plains with minimal damage to the stand (Anderson and Matches 1983). Our results indicate that leaving a $20-\mathrm{cm}$ stubble will result in stand improvement should that be the primary objective. Two years' data indicated that the 41/10 management resulted in optimum yield and quality of the harvest regimes for big bluestem in Missouri. It appeared that declining leaf quality with maturation may be just as important or more so than accumulation of stem material due to maturation in the downward quality trend. Since our data agree with results of Perry and Baltensperger (1979), it is recommended that grasses such as big bluestem be managed to avoid leaf longevity. Systems similar to intensive early stocking (Launchbaugh and Owensby 1978) with ample regrowth time before dormancy are recommended. For the area east of the Missouri River, use of big bluestem and similar tall grass species in complementary grazing systems will often result in moving cattle from cool-season species onto warm-season pasture before the former is fully utilized. This small sacrifice may be required in order to gain the larger benefit of proper warm-season pasture use through reduced leaf longevity. Results from studies such as this may be more solidly confirmed by long-term data collection (5-10 years).

\section{Literature Cited}

Anderson, Bruce, and A.G. Matches. 1983. Forage yield, quality and persistence of switchgrass and caucasian bluestem. Agron. J. 75:119-124.

Anderson, Bruce. 1986. Warm season grasses: Facts and fantasy. p. 11-20. In: P.D. Ohlenbusch (ed.) Proc. Four State Grassland Manage. Workshop North West Missouri State Univ. Maryville, Mo.

Beaty, E.R., R.L. Stanley, and J. Powell. 1968. Effect of height of cut on yield of Pensacola bahiagrass. Agron. J. 60:356-358.

Conard, E.C., and D.C. Clanton. 1963. Cool-season, warm-season pastures needed. Nebraska Agr. Exp. Sta., Beef Cattle Prog. Rep. p. 11-13.

Ethredge, Jerome, E.R. Beaty, and R.M. Lewrence. 1973. Effects of clipping height, clipping frequency and rates of nitrogen on yield and energy content of coastal bermudagrass. Agron. J. 65:717-719.

Finch, J.P. 1974. Morphological development, carbohydrate trends and net carbon exchange rates of Panicum virgatum and Andropogon caucasicus. MS Thesis. University of Missouri-Columbia.

Heinze, P.H. and A.E. Murneek. 1940. Comparative accuracy and efficiency in determination of carbohydrates in plant material. Missouri Agr. Exp. Sta. Res. Bull. 314.

Kinsinger, F.E., and H.H. Hopkins. 1961. Carbohydrate content of underground parts of grasses as affected by clipping. J. Range Manage. 14:9-12.

Krueger, C.R., R.A. Moore, and L.B. Embry. 1974. Cow calf evaluation of native and tame pasture systems for six grazing seasons, p. 249-255. In: Proc. 12th Int. Grassl. Congr.

Launchbaugh, J.L., and C.E. Owensby. 1979. Kansas Rangelands: Their management based on a half century of research. Kansas Agr. Ext. Sta. Bull. 622. Kansas State Univ., Manhattan 66506.

Marten, G.C., and R.F. Barnes. 1980. Prediction of energy digestibility of forages with in vitro rumen fermentation and fungal enzyme systems. In: W.J. Pidgen, C.C. Balch, and M. Graham (eds.) Standardization of analytical methodology for fees. Int. Dev. Res. Ctr., Ottawa, Can.

McKendrick, J.D., C.E. Owensby, and R.M. Hyde. 1975. Big bluestem and Indiangrass vegetative reproduction and annual reserve carbohydrate and nitrogen cycles. Agro-ecosystems 2:79-93.

Owensby, C.E., J.R. Rains, and J.D. McKendrick. 1974. Effects of one year of intensive clipping on big bluestem. J. Range Manage. 27:341-343.

Owensby, C.E., Ed. F. Fisher, and J.R. Rains. 1977. Carbohydrate and nitrogen reserve cycles for continuous, season-long and intensive early stocked Flint Hills bluestem range. J. Range Manage. 30:258-260. 
Perry, L.J. Jr., and D.D. Baltensperger. 1979. Leaf and stem yields and forage quality of three $\mathrm{N}$-fertilized warm season grasses. Agron. J. 71:355-358.

Roundtree, B.H., A.G. Matches, and F.A. Martz. 1974. Season too long your pasture? Crops Soils 26:7-10.

Smith, Dale. 1969. Removing and analyzing total nonstructural carbohydrates from plant tissue. Univ. Wisconsin Coll. Agr. and Life Sci. Res. Rep. 41 .
Sweeney, R.A., and P.R. Rexroad. 1987. Comparison of the LECO FP 228 "Nitrogen Determinator" with AOAC copper catalyst Kjeldahl method for crude protein. J. of the AOAC. 70:1028-1030.

Twidwell, E.K., K.D. Johnson, J.H. Cherney, and J.J. Volenec. 1986. Forage quality of switchgrass morphological components. p. 145. In Agron. Abstr. New Orleans, La. 